\title{
Petrological features of picrobasaltic melts on Lanzarote, Canary Islands
}

\author{
L.S. Canhimbue ${ }^{1}$, S.V. Mezhelovskaya ${ }^{2}$, K.G. Erofeeva ${ }^{3}$ \\ ${ }^{1}$ Sergo Ordzhonikidze Russian State University for Geological Prospecting, Department of \\ Petrography, Moscow, Russia \\ ${ }^{2}$ Sergo Ordzhonikidze Russian State University for Geological Prospecting, Department of General \\ Geology and Geological Mapping, Moscow, Russia \\ ${ }^{3}$ Institute of Geology of Ore Deposits, Petrography, Mineralogy and Geochemistry of the Russian \\ Academy of Sciences, Laboratory of Petrography, Moscow, Russia
}

\begin{abstract}
The paper discusses issues related to the petrology of picrobasaltic melts forming lava flows on Lanzarote, Canary Islands. During ascientific and educational expedition on the aforementioned island, lava flows of picro basalt of the third phase of the 1731-1732 eruption were studied and tested. Preference was given to the wellpreserved streams in the west and south of the island thatare accessible for direct study. Volcanogenic-sedimentary associations were identified in the studied outcropsand described, the structural and textural features of the flows were characterized, and samples with mantle rock xenoliths were taken for petrological reconstructions. New geochemical data onrocks and minerals are presented. It was established that the temperature of the initial melt was $1100-1180^{\circ} \mathrm{C}$. Large harzburgitephenocrysts in picro basalt are xenocrysts formed as a result of melting and disintegration of mantle xenoliths.
\end{abstract}

\section{Introduction}

The presence of basic magmatism is characteristic of various geotectonic sittings [1]. For volcanic islands, mainmagmatism is predominant (over $95 \%$ of the volume), whereas the generation of melts occurs at mantle levels under the influence of thermal anomaly (plume). The presence of xenoliths in basalts makes it possible to identify the composition of the mantle beneath the region and estimate the contribution of mantle rocks to the formation of basaltic melts.

The intense magnetic activity on the Canary Islands, as well as the young age of magmatism ,i.e., during the past 500 years according to [2] makes the Canary archipelago one of the crucial objects for studying oceanic island magmatism. The islands of the Canary archipelago have a highly dissected relief and are often eroded and brought to the surface near coastal deposits, which makes these sites attractive for geological study.

Over the past two decades, deposits of the islands of the Canary archipelago have been extensively studied and characterized by a complex of geological and geophysical methods $[2,3,4,5,6,7,8]$. Thus, today, the Canary archipelago is one of the best-studied 
volcanic chains in the world. The origin of melts from the islands of the Canary archipelago is widely discussed in the world literature $[5,9,14,16,18,19]$.

This article is devoted to the study of the evolution of melts of the third phase of the eruption of Lanzarote Island, represented by picrobasalts containing xenoliths of mantle rocks.

\section{Geological position}

The Canary Archipelago is formed of 7 islands and several smaller erosive remains. Tectonically, the islands are located near the margin of the northwestern African continental shelf. Moreover, the composition of xenoliths found on all islands suggests the presence of an oceanic type of crust below the archipelago, whose age is estimated as 60 $\mathrm{Ma}[20]$. The above circumstances indicate its formation due to the mantle thermal anomaly located inside the lithosphere plate, which is a source of magmas that feed the active volcanoes of the islands.

Lanzarote is the easternmost island (Fig. 1). Its tectonic position is an intra-plate area located on the North African plate that encompasses both the oceanic and the continental crust.

The island stretches in a northeasterly direction and is parallel to the continental marginof Africa. It rises about $2500 \mathrm{~m}$ from the seabed, whereas most of the volcanic structure is submerged. It is connected in its underwater part with the island of Fuerteventura, as indicated by the same type of volcanism and identical equalage composition of sedimentary rocks, and the thickness of the water between the islands does not exceed $40 \mathrm{~m} \mathrm{[11].} \mathrm{The} \mathrm{base} \mathrm{of} \mathrm{the} \mathrm{island} \mathrm{was} \mathrm{formed} \mathrm{during} \mathrm{the} \mathrm{Oligocene} \mathrm{over} \mathrm{oceanic}$ deposits with an age of approximately 65-55 Ma and is composed of material from underwater volcanic eruptions and plutonic rocks. 


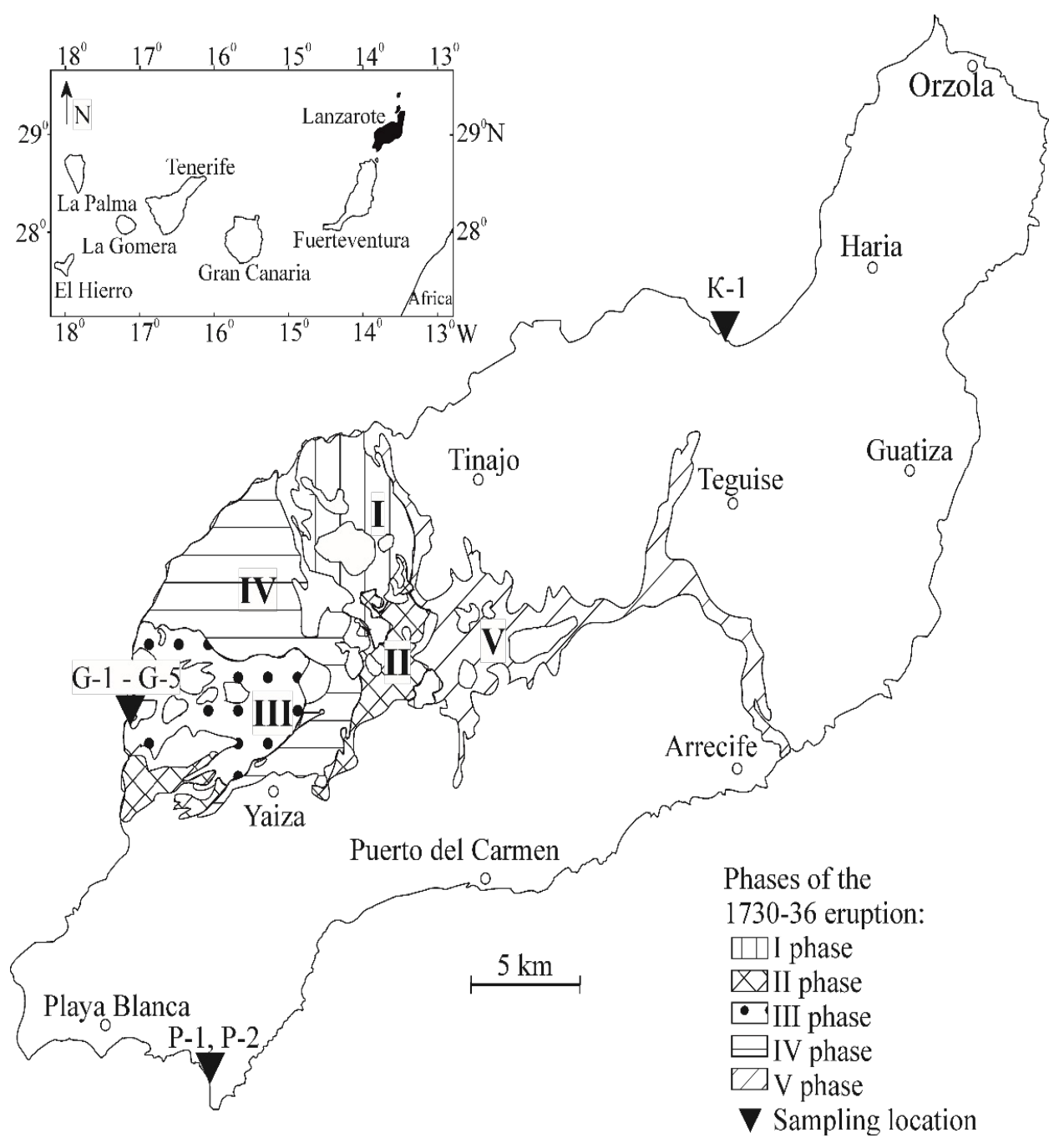

Fig. 1. Map of Lanzarote showing the distribution of products of the five eruptive phases on the island (after Carracedo\& Troll 2016) with sampling points.

Recent volcanoes are grouped in a central rift zone from northeast to southwest, with 1730-1736 vents and deposits that are an expression of the "active" volcanic status of the island [2]. The 1730-1736 eruption is divided into 5 phases (Fig. 1). The composition of magma during the initial phase gradually changed from melanepheline sites through basanites to alkaline basalts. In the remaining 4 phases of the eruption, magma evolved from basanites to olivine tholeiites.

The object of the study was picrobasalt, attributed [12] to the third phase of the volcanic eruption (July 1731 - January 1732). The studied samples were selected from recent, wellpreserved lava flows with primary textural, structural, and mineralogical features in the south-west of the island near the El Golfo village. These rocks contain xenoliths of various compositions: (1) mantle xenoliths according to [21, 22] may be fragments of the old suboceanic mantle subjected to metasomatism and partial melting; (2) xenoliths of 
sedimentary rocks (calcareous-silicate and siliceous rocks, subordinate to limestones, clay, and sandstones), most of which are metamorphosed and metasomatized[10].

\section{Methods of research}

For petrological study, 8 rock samples were taken from different points on Lanzarote island. Of particular interest were rocks with large and numerous mantle xenoliths. Thus, 5 samples of picrobasalts were taken near the El Golfo village. To compare the composition of rocks, 2 samples of basalts in the south of the island at Playa Papagayo and 1 sample in the north at Caleta de Famarawere taken.

The mineralogical composition of the rocks was studied in 8 thin sections. The composition of rock-forming minerals was determined in the laboratory for mineral matter analysis at IGEM RAS using a JEOL (JXA-8200) electron probe analyzer equipped with 5 wave spectrometers at an accelerating voltage of $20 \mathrm{kV}$, a Faraday cup current of $20 \mathrm{nA}$, and a beam diameter of $1 \mu \mathrm{m}$. Exposure times for all elements measured in olivine, pyroxene, and plagioclase were $10 \mathrm{~s}$ at the peak and $5 \mathrm{~s}$ on the background on both sides.Forty mineral composition analyses were performed.

The content of major and trace elements on 3 samples was determined by X-ray fluorescence analysis (XRF) using an S4 Pioneer spectrometer (Bruker, Germany) with a 4 $\mathrm{kW}$ rhodium tube and a $75 \mu \mathrm{m}$ beryllium window. Sample preparation for analysis was carried out according to the method described in [23]. The microelement composition of rocks was determined by inductively coupled plasma mass spectrometry (ICP-MS) on a Thermo Fisher Scientific 2 apparatus at the GIN RAS.Thesamples were prepared for analysis by acid decomposition according to the procedure described in. The accuracy of the analysis was monitored by measuring samples of the international standard MUH-1 and WG-1.A geothermobarometry[24] was used to determine the crystallization temperature of the melt. Calculation of temperature parameters was carried out according to equation 32 .

\section{Petrogeochemical characteristics of picrobasalt}

On the west coast of Lanzarote, outcrops are extended;almost black streams of chilled magma, in the roof of which the structures of quenching zones with pahoehoe and numerous lava breccias are often preserved. Clumps of basalts of various sizes containing large xenoliths of mantle rocks of $10 \mathrm{~cm}$ in size were observed everywhere along the coast. Powerful pyroclastic flows are located in close proximity to the outcrops and are composed of tuffs with numerous volcanic bombs and lapilli.

According to petrochemical characteristics (Table 1), picrobasalts correspond to low potassium tholeiitic basalts with thepredominance of $\mathrm{Na}$ over $\mathrm{K}\left(\mathrm{K}_{2} \mathrm{O} / \mathrm{Na}_{2} \mathrm{O}=0.3-0.4\right)$. According to the TAS classification, the volcanic compositions are located in the field of basalts, less frequently,basanites.

(MORB) of normal (N-) and enriched (E-) types, island arcs (IAB) and oceanic islands (OIB). The rocks are normalized to a primitive mantle according to [29].

Table 1. Whole-rock composition of 3rd eruptive phase on Lanzarote

\begin{tabular}{llllllllllll} 
Sample & K-1 & P-1 & G-4 & M-42 & M-11 & Sample & K-1 & P-1 & $\begin{array}{l}\text { G- } \\
4\end{array}$ & M-42 & M-11 \\
\hline
\end{tabular}




\begin{tabular}{llllllllllll}
$\mathrm{SiO}_{2}$ & 46.05 & 42.43 & 47.94 & 46.85 & 47.5 & $\mathrm{Cs}$ & 0.3 & 0.3 & 0.3 & - & - \\
$\mathrm{TiO}_{2}$ & 2.62 & 4.61 & 2.88 & 2.51 & 2.59 & $\mathrm{Ba}$ & 257 & 422 & 183 & 316 & 284 \\
$\mathrm{Al}_{2} \mathrm{O}_{3}$ & 12.46 & 11.23 & 12.77 & 13.26 & 13.48 & $\mathrm{Y}$ & 18 & 23 & 19 & 20 & 18 \\
$\mathrm{Fe}_{2} \mathrm{O}_{3}$ & 12.2 & 12.84 & 13.26 & 11.49 & 10.95 & $\mathrm{Zr}$ & 195 & 390 & 192 & 190 & 179 \\
$\mathrm{MnO}$ & 0.19 & 0.17 & 0.17 & 0.17 & 0.17 & $\mathrm{Nb}$ & 41 & 85 & 35 & 36 & 32 \\
$\mathrm{MgO}$ & 11.73 & 7.11 & 8.18 & 10.6 & 10.07 & $\mathrm{La}$ & 28 & 43 & 19 & 27 & 19 \\
$\mathrm{CaO}$ & 9.44 & 12.99 & 9.88 & 9.61 & 9.71 & $\mathrm{Ce}$ & 58 & 91 & 42 & 47 & 34 \\
$\mathrm{Na} 2 \mathrm{O}$ & 3.02 & 2.54 & 2.83 & 3.2 & 3.23 & $\mathrm{Pr}$ & 7 & 11 & 5 & - & - \\
$\mathrm{K} \mathrm{O}_{5}$ & 0.78 & 1.12 & 0.77 & 0.72 & 0.75 & $\mathrm{Nd}$ & 29 & 45 & 23 & - & - \\
$\mathrm{P}_{2} \mathrm{O}_{5}$ & 0.38 & 0.48 & 0.27 & 0.37 & 0.42 & $\mathrm{Sm}$ & 6 & 8.9 & 5.4 & - & - \\
$\mathrm{LOI}$ & 0.8 & 4.15 & 0.8 & 0.9 & 0.8 & $\mathrm{Eu}$ & 2 & 2.8 & 1.9 & - & - \\
$\mathrm{Total}$ & 99.67 & 99.68 & 99.75 & 98.78 & 98.87 & $\mathrm{Gd}$ & 5.7 & 7.8 & 5.4 & - & - \\
$\mathrm{Mg} \#$ & 63 & 50 & 52 & 63 & 63 & $\mathrm{~Tb}$ & 0.8 & 1 & 0.8 & - & - \\
$\mathrm{Trace}$ & elements, & $\mathrm{ppm}$ & & & & $\mathrm{Dy}$ & 4 & 5.3 & 4.1 & - & - \\
$\mathrm{V}$ & 196 & 345 & 221 & 282 & 287 & $\mathrm{Ho}$ & 0.7 & 0.9 & 0.7 & - & - \\
$\mathrm{Cr}$ & 699 & 160 & 439 & 527 & 460 & $\mathrm{Er}$ & 1.7 & 2.2 & 1.8 & - & - \\
$\mathrm{Sc}$ & 19 & 23 & 22 & - & - & $\mathrm{Tm}$ & 0.2 & 0.3 & 0.2 & - & - \\
$\mathrm{Co}$ & 58 & 39 & 51 & 41 & 44 & $\mathrm{Yb}$ & 1.3 & 1.6 & 1.3 & - & - \\
$\mathrm{Ni}$ & 558 & 85 & 285 & 290 & 245 & $\mathrm{Lu}$ & 0.2 & 0.2 & 0.2 & - & - \\
$\mathrm{Cu}$ & 69 & 75 & 83 & 68 & 71 & $\mathrm{Hf}$ & 4.2 & 8.3 & 4.3 & - & - \\
$\mathrm{Zn}$ & 107 & 98 & 117 & - & - & $\mathrm{Ta}$ & 0.7 & 0.7 & 0.5 & - & - \\
$\mathrm{Ga}$ & 17 & 22 & 20 & - & - & $\mathrm{Th}$ & 2.8 & 4.2 & 1.9 & 8 & 6 \\
$\mathrm{Rb}$ & 16 & 20 & 16 & 17 & 16 & $\mathrm{U}$ & 2.9 & 5.6 & 2.5 & - & - \\
$\mathrm{Sr}$ & 514 & 757 & 427 & 480 & 396 & $\mathrm{~Pb}$ & 2.7 & 2.1 & 1.8 & - & - \\
\hline & & & & & &
\end{tabular}

* The total content of iron oxides. Samples M-42, M-11 are picrobasalt of the volcanoes El Quemado and Mña. Rajada[2] 


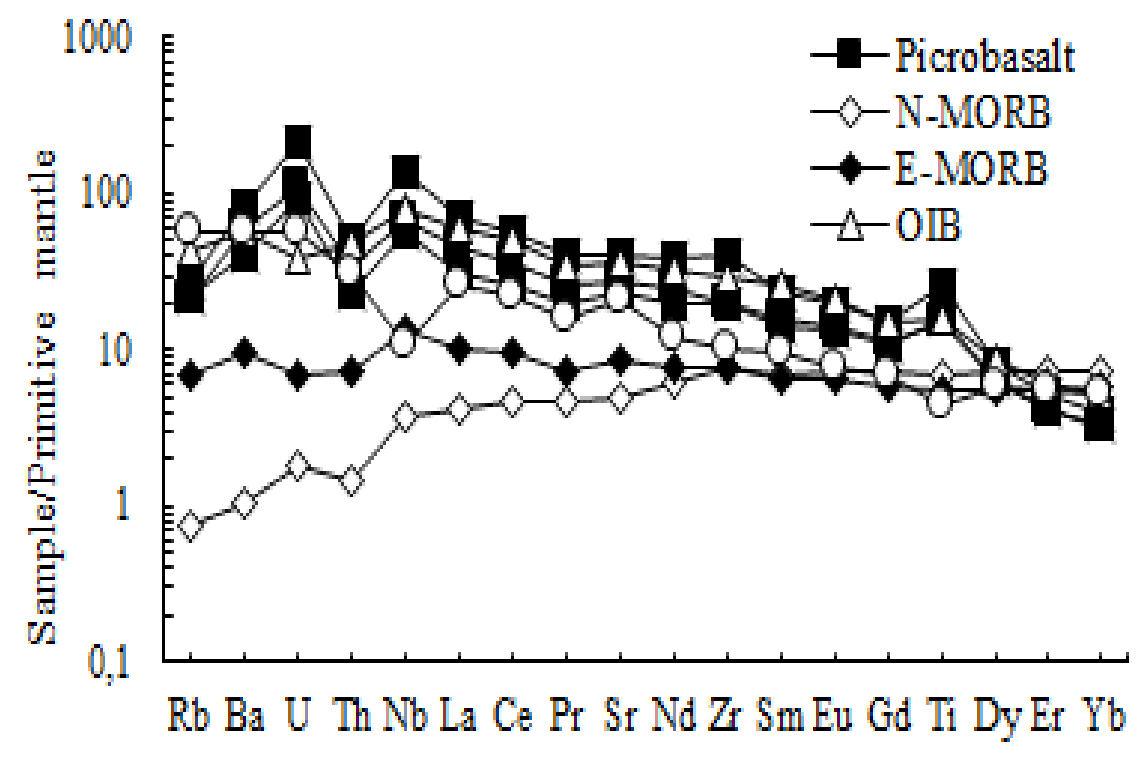

Fig. 2. Multi-element variation diagram for picrobasalt of the third phase of the eruption on Lanzarote and basalts of different geodynamic settings (according to Sun \& McDonough 1989): mid-ocean ridges 

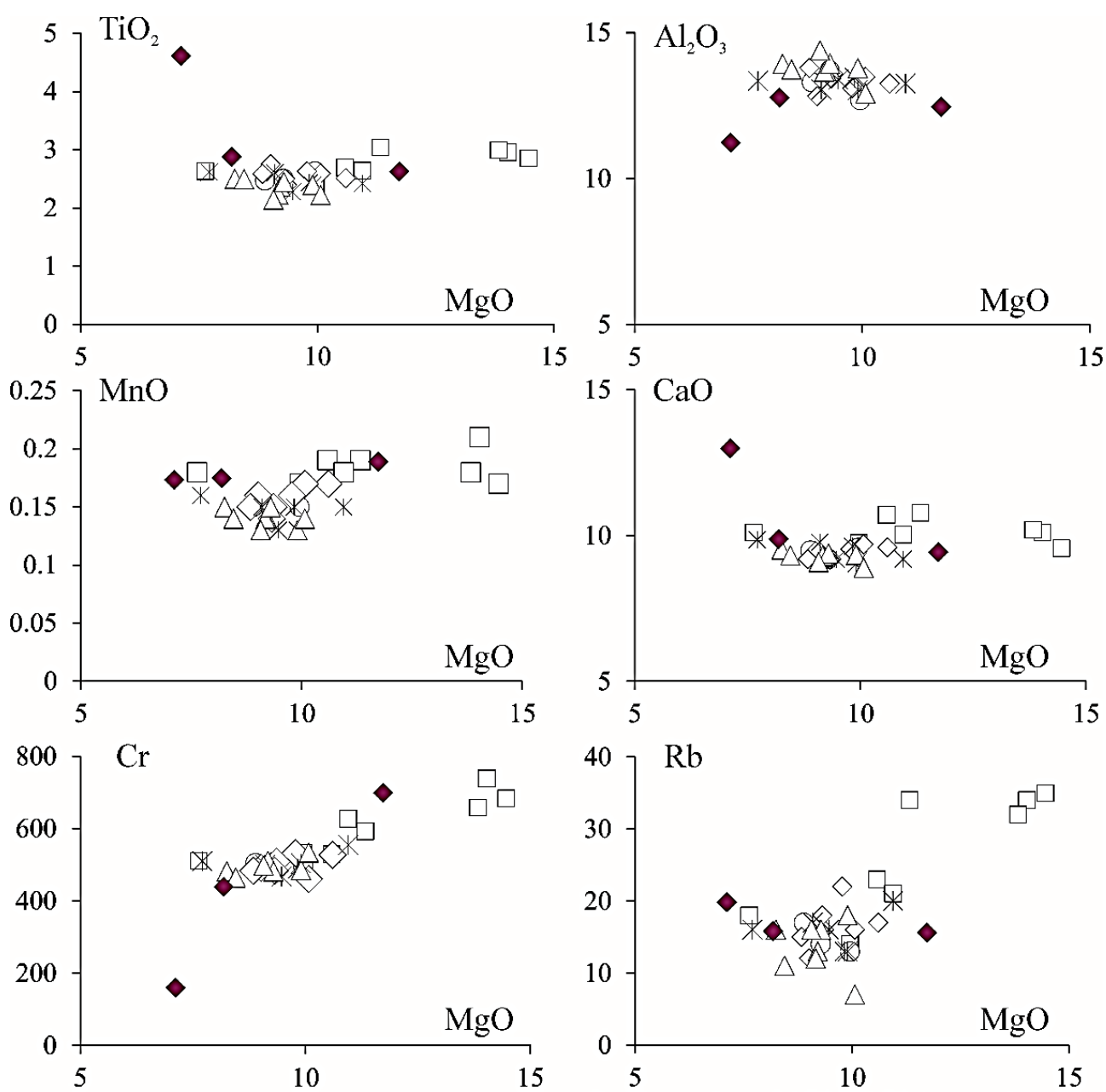

$\checkmark$ Picrobasalt

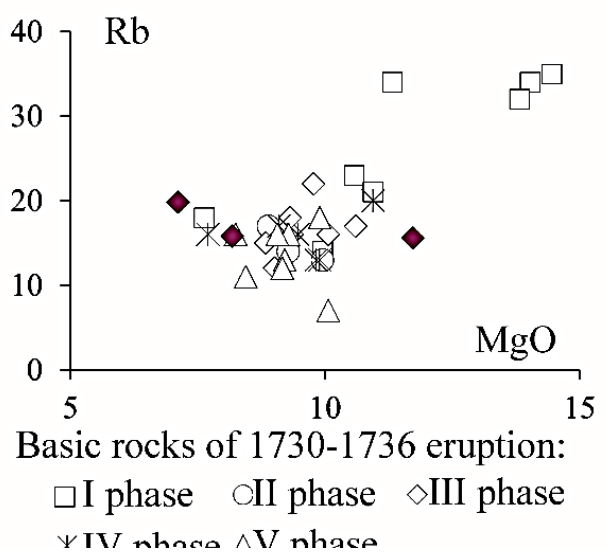

Fig. 3.Variational diagrams $\mathrm{MgO}$ - rock-forming oxide (wt.\%) and $\mathrm{MgO}$ - microelements (ppm) for the studied picrobasalt and mafic rocks of different phases of the 1730-1736 Lanzarote eruption (Carracedo at al. 1990).

The studied rocks in terms of the content of all major elements are comparable with the known compositions of picrobasalt of the third phase of the eruption (Fig. 3). At the same time, rocks of all phases of eruptions on Lanzarote as a whole have similar variations in the contents of major and trace elements forming a trend of changes in their compositions with $\mathrm{MgO}$ variations from 7 to $12 \mathrm{wt} \%$ on binary diagrams. The decrease in the contents of $\mathrm{MgO}$ in rocks from 12 to 8 wt. \% is accompanied by a decrease in the concentrations of $\mathrm{TiO}_{2}$, $\mathrm{MnO}, \mathrm{Cr}, \mathrm{Ni}$, and $\mathrm{Rb}$ and an increase in $\mathrm{Al}_{2} \mathrm{O}_{3}$ contents. Inflection of the trend at the level of 8 wt. $\% \mathrm{MgO}$ is accompanied by a smooth increase in the concentrations of $\mathrm{TiO}_{2}, \mathrm{MnO}$, $\mathrm{CaO}$, and $\mathrm{Rb}$ and a decrease in $\mathrm{Al}_{2} \mathrm{O}_{3}$ contents.

The multi-element trace of the distribution of rare-earth elements (REE) of the studied rocks isweakly fractionated and are characterized by enrichment oflight $\left([\mathrm{La} / \mathrm{Sm}]_{\mathrm{N}}=1.7-\right.$ 
2.3) and heavy $\left([\mathrm{Gd} / \mathrm{Yb}]_{\mathrm{N}}=3.3-3.9\right)$ REE and positive anomalies of $\mathrm{Nb}(\mathrm{Nb} / \mathrm{Nb} *=1.7-2.2)$ and Ti (Fig. 2). The REE trace of picrobasalts is similar to those for basalts of oceanic islands (OIB, Fig. 2).

Picrobasaltare dark gray rocks with an almond-stone, porous texture and contain large $(4-5 \mathrm{~cm})$ peridotite xenoliths. The porphyry structure of microbasalts is formed by olivine phenocrysts (30-35 vol.\%). They are embedded in fine-grained olivine-pyroxeneplagioclase bulk rocks.

Olivine phenocrysts $(\mathrm{Ol}-\mathrm{Ph})$ form large $(0.3-0.5 \mathrm{~mm})$ resorbed grains of angular and irregular shape (Fig. 4). The central parts of the grains are homogeneous and characterized by high $\mathrm{Mg} \# 89-91(\mathrm{Mg} \#=\mathrm{Mg} /(\mathrm{Mg}+\mathrm{Fe}) * 100)$, Ni and $\mathrm{Cr}$ concentrations and low concentrations of incompatible elements ( $\mathrm{Al}, \mathrm{Ti}, \mathrm{Mn}$ ) (Table 2). The core sections are surrounded by a narrow (less than $0.005 \mathrm{~mm}$ ) rim of less magnesian composition ( $\mathrm{Mg}$ \# $85)$, characterized by a low Ni content and higher contents of incompatible elements. The $\mathrm{Ol}-\mathrm{Ph}$ rims contain spinel inclusions with chromium number $\mathrm{Cr} \# 25-45(\mathrm{Cr} \#=\mathrm{Cr} /(\mathrm{Cr}+$ $\mathrm{Al}+\mathrm{Fe}) * 100)$.

The groundmass of porphyry picrobasalt has a gabbro structure and consists of olivine (10 vol.\%), pyroxene (45 vol.\%), plagioclase (35 vol.\%), and magnetite. Olivine forms small (up to $0.05 \mathrm{~mm}$ ) isometric grains with $\mathrm{Mg} \# 84-85$ and is comparable in composition to the rim parts of Ol-Ph (Table 2).

Pyroxene forms prismatic grains up to $0.3 \mathrm{~mm}$ in elongation, most often smaller (less than $0.05 \mathrm{~mm}$ ) hypidiomorphic grains, and is represented mainly by diopside with $\mathrm{Mg}$ \# 68 $76\left(\mathrm{Wo}_{51-54} \mathrm{En}_{34-40} \mathrm{Fs}_{9-11}\right)$ (Table 2). More rarely diopsideis surrounded by narrow (less than $0.005 \mathrm{~mm}$ ) Ol-Ph rims. Magnetite is present as inclusions in pyroxene-forming veins along cleavage cracks. The interstices filled with plagioclase are represented by labrador $\left(\operatorname{An}_{62}\right.$ ${ }_{69}$ ). Magnetite forms rounded grains in the bulk of the rock.Amphibole reaction fringes that surround olivine and pyroxene grains are rare.

Table 2. Composition of olivine (Ol) and pyroxene (Px) from picrobasaltic lavas and xenolith of harzburgite (in mas. \%)

\begin{tabular}{|c|c|c|c|c|c|c|c|c|c|c|c|}
\hline \multirow{2}{*}{$\begin{array}{l}\text { Type } \\
\mathrm{Ol}\end{array}$} & \multicolumn{3}{|c|}{ Groundmass } & \multicolumn{5}{|c|}{ Phenocrystal } & \multicolumn{3}{|c|}{ Xenolith } \\
\hline & Core & Core & Rim & Core & Rim & Core & Rim & Core & Core & Rim & Core \\
\hline $\mathrm{SiO}_{2}$ & 40.36 & 40.03 & 39.74 & 41.52 & 39.92 & 41.21 & 40.57 & 41.12 & 40.86 & 41.30 & 41.65 \\
\hline $\mathrm{TiO}_{2}$ & 0.05 & 0.05 & 0.12 & 0.03 & 0.04 & 0.01 & 0.01 & 0.01 & 0.02 & 0.01 & 0.01 \\
\hline $\mathrm{Al}_{2} \mathrm{O}_{3}$ & 0.03 & 0.06 & 0.06 & 0.01 & 0.03 & 0.02 & 0.03 & 0.00 & 0.01 & 0.01 & 0.00 \\
\hline $\mathrm{Cr}_{2} \mathrm{O}_{3}$ & 0.04 & 0.01 & 0.00 & 0.04 & 0.06 & 0.02 & 0.00 & 0.03 & 0.01 & 0.01 & 0.01 \\
\hline $\mathrm{FeO}$ & 13.91 & 14.79 & 16.10 & 9.12 & 14.32 & 10.08 & 13.70 & 8.22 & 8.49 & 8.54 & 8.33 \\
\hline $\mathrm{MnO}$ & 0.15 & 0.23 & 0.30 & 0.04 & 0.20 & 0.20 & 0.21 & 0.12 & 0.12 & 0.13 & 0.13 \\
\hline $\mathrm{MgO}$ & 44.76 & 44.04 & 42.76 & 48.39 & 44.08 & 47.89 & 44.77 & 48.38 & 49.26 & 48.85 & 48.45 \\
\hline $\mathrm{NiO}$ & 0.20 & 0.25 & 0.20 & 0.36 & 0.24 & 0.39 & 0.31 & 0.37 & 0.41 & 0.41 & 0.40 \\
\hline $\mathrm{CaO}$ & 0.24 & 0.21 & 0.35 & 0.05 & 0.22 & 0.04 & 0.09 & 0.11 & 0.05 & 0.06 & 0.05 \\
\hline Total & 99.74 & 99.67 & 99.63 & 99.55 & 99.09 & 99.86 & 99.70 & 98.36 & 99.24 & 99.32 & 99.02 \\
\hline Mg\# & 85 & 84 & 83 & 90 & 85 & 89 & 85 & 91 & 91 & 91 & 91 \\
\hline Type & \multicolumn{8}{|c|}{ Groundmass } & \multicolumn{3}{|c|}{ Xenolith } \\
\hline Px & \multicolumn{8}{|c|}{ DiopsideDiopsideDiopsideDiopsideDiopsideDiopside } & \multirow{2}{*}{\multicolumn{2}{|c|}{$\begin{array}{r}\text { Estatite } \\
5701\end{array}$}} & nstatite \\
\hline $\mathrm{SiO}_{2}$ & 47 & 96 & 41.97 & 46.74 & 42.42 & 41.3 & & 47.27 & & & 56.94 \\
\hline $\mathrm{TiO}_{2}$ & & 83 & 5.64 & 3.32 & 4.68 & 5.6 & & 3.13 & & & 0.02 \\
\hline $\mathrm{Al}_{2} \mathrm{O}_{3}$ & & .01 & 10.21 & 6.21 & 8.50 & 10.6 & & 5.79 & & & 2.32 \\
\hline
\end{tabular}




\begin{tabular}{lrrrrrrrr}
$\mathrm{Cr}_{2} \mathrm{O}_{3}$ & 0.01 & 0.04 & 0.00 & 0.10 & 0.02 & 0.04 & 0.39 & 0.41 \\
$\mathrm{FeO}$ & 7.10 & 8.25 & 7.57 & 8.36 & 8.43 & 7.45 & 5.43 & 5.37 \\
$\mathrm{MnO}$ & 0.12 & 0.12 & 0.12 & 0.14 & 0.10 & 0.18 & 0.15 & 0.18 \\
$\mathrm{NiO}$ & 0.00 & 0.00 & 0.04 & 0.01 & 0.01 & 0.00 & 0.10 & 0.12 \\
$\mathrm{MgO}$ & 12.77 & 10.04 & 12.39 & 10.79 & 10.35 & 12.61 & 33.30 & 33.38 \\
$\mathrm{CaO}$ & 22.84 & 22.59 & 22.47 & 22.25 & 22.39 & 22.56 & 0.56 & 0.55 \\
$\mathrm{Na} 2 \mathrm{O}$ & 0.49 & 0.55 & 0.46 & 0.47 & 0.56 & 0.45 & 0.02 & 0.01 \\
$\mathrm{~K}_{2} \mathrm{O}$ & 0.00 & 0.01 & 0.01 & 0.01 & 0.02 & 0.02 & 0.00 & 0.00 \\
$\mathrm{Total}$ & 100.11 & 99.42 & 99.32 & 97.74 & 99.47 & 99.50 & 99.35 & 99.29 \\
$\mathrm{Mg} \#$ & 76 & 68 & 74 & 70 & 69 & 75 & 92 & 92 \\
\hline
\end{tabular}
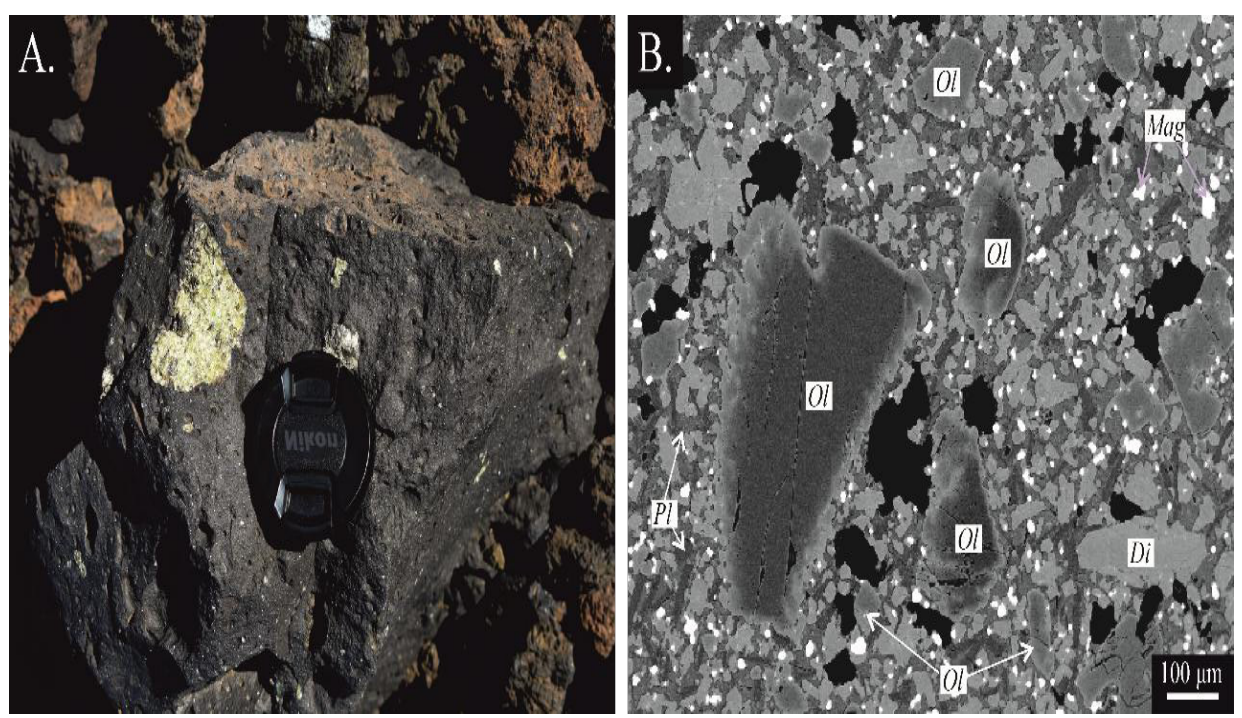

Fig. 4.Picrobasalt of Lanzarote. (A) Photograph of picrobasalt. The rock contains large xenoliths (light green) of mantle rocks. (B) Microphotography of picrobasalt. The porphyry structure is formed by large phenocrysts of olivine (Ol). The groundmass of the rock is composed of small grains of olivine and clinopyroxene (Di), interstices filled with plagioclase (Pl) fills the interstitium. The image in backscattered electrons.

Mantle xenoliths in picrobasalts are mainly represented by pyroxenites and dunites[2, 9, $12,15,21]$, harzburgites are less common. Harzburgitexenoliths of a harzburgite composition composed of large $(4-5 \mathrm{~cm})$ grains of olivine (60 vol.\%) and orthopyroxene (40 vol.\%) were studied. Large hypidiomorphic grains of olivine with $\mathrm{Mg} \#$ 90-91 are characterized by a high $\mathrm{Ni}$ content and low concentrations of incompatible elements (Table 2).

According to the content of trace elements, xenolithicolivines are comparable with the central parts of $\mathrm{Ol}-\mathrm{Ph}$ on picrobasalt.

Inclusions of chrome spinel $\left(\mathrm{Al}_{2} \mathrm{O}_{3} 33\right.$ wt.\%) with $\mathrm{Cr}$ \# 36 are present in some grains. At the contact of harzburgite olivine with the host picrobasalt mass, its dissolution is substantiated by the formation of diopside ( $\left.\mathrm{Mg} \# 85-86, \mathrm{Wo}_{48} \mathrm{En}_{44} \mathrm{Fs}_{8}\right)$. Orthopyroxene forms large hypidiomorphic grains and is represented by enstatite $\left(\mathrm{Wo}_{1} \mathrm{En}_{87-88} \mathrm{Fs}_{11}\right)$ with Mg\# 92 (Table 2). 


\section{Discussion}

The porphyritic texture of picrobasalt indicates that the melt which formed lava flows contained crystalline mineral phases. This can oftenindicate the existence of an intermediated magmatic chamber in which crystallization of phenocryst minerals could occur $[18,26]$. At the same time, phenocrysts can be xenocrysts, melt fragments of the disintegration of rocks trappedbythe melt during ascent(Larrea et al. 2013). In any case, phenocrysts are an indicator of events in the formation of the initial melt for volcanic rocks and their study allows us to draw conclusions about the previous evolutionary stages of the initial magma.

Recent studies [14, 16, 23] have shown that olivine is an important petrogenetic indicator. Reliable data on the distribution of trace elements have been established for some elements (e.g., Ni, Co, Mn, Cr) of olivine phenocrysts from basalts formed in different tectonic settings $[27,28]$, separated by trace elements and dispersed through olivine into three groups, whose distribution depends on (1) the ionic radius close to $\mathrm{Mg}(\mathrm{Ni}, \mathrm{Mn}, \mathrm{Co}$, $\mathrm{Cu}, \mathrm{Zn}, \mathrm{Li}$ ); (2) melt composition (Ti, Zr, Nb, Y, P); (3) controlled by temperature during equilibrium crystallization of the mineral $(\mathrm{Cr}, \mathrm{Al}, \mathrm{V}, \mathrm{Sc}, \mathrm{Ca}, \mathrm{Na})$, which revealed systematic differences between mantle substrate compositions,, element distribution mechanisms in olivine, and their potential for use in geobarometry and interpretation of mantle processes. Generalized information on the concentrations of trace elements in olivine from different basaltic melts revealed patterns of their distribution depending on the source of melting.

In picrobasalts, Ol-Ph has a sharp and clear boundary between the homogeneous central part and the narrow marginal zone. Assuming the distribution coefficient $\mathrm{K}_{\mathrm{D}}{ }^{\mathrm{Fe}-\mathrm{Mg}}$ olivinemelt $=0.3 \pm 0.03$ [25], $\mathrm{Mg} \#$ of the central parts of $\mathrm{Ol}-\mathrm{Ph}$ is excessive with respect to the contained melt, which may indicate its crystallization from a more primitive melt. However, in terms of magnetism and the content of trace elements, such as $\mathrm{Ni}, \mathrm{Ca}$, and $\mathrm{Ti}$, the central parts of Ol-Ph differ from the marginal parts and are comparable with the olivine of harzburgitexenoliths. On the variation diagrams (Fig. 5), the compositional points of the central parts of Ol-Ph and olivine from harzburgite xenolith form a local area of points with $\mathrm{Mg}$ \# from 89 to 92 located in the region of olivine compositions of dunite and harzburgite xenoliths.

$\mathrm{Mg} \#$ of the olivine in the bulk corresponds to $\mathrm{Mg \#}$ of the surrounding melt. According to the content of trace elements, the olivine of the groundmassis similar to the compositions of the $\mathrm{Ol}-\mathrm{Ph}$ rims. This olivine enriched of incompatible elements $\mathrm{Al}, \mathrm{Ca}$, and This likely to indicate an enriched source of the melts.

Given The significant differences in the content of trace elements between Ol-Ph and groundmass olivine, as well as the geochemical similarity of olivine in harzburgite xenoliths and central parts of the $\mathrm{Ol}-\mathrm{Ph}$, wecan assume that $\mathrm{Ol}-\mathrm{Ph}$ is most likely a product of harzburgite xenoliths disintegration, which was accompanied by the resorption of xenolithic olivine which affected its morphology. During crystallization from a melt of liquidus olivine (groundmass olivine), the central parts of Ol-Ph were surrounded by narrow rims. This mechanism explains the geochemical similarity of the bulk olivine and the $\mathrm{Ol}-\mathrm{Ph}$ rim.

The presence of rare inclusions of low-chromium spinel and magnetite in the $\mathrm{Ol}-\mathrm{Ph}$ and groundmass olivine boundaries and at the same time their more frequent occurrence in inclusions in pyroxene indicate that crystallization of spinel and magnetite occurred at the final stage of olivine fractionation, probably synchronously with the crystallization of large grains of groundmass pyroxene .Plagioclase was the last to crystallize from the melt. 

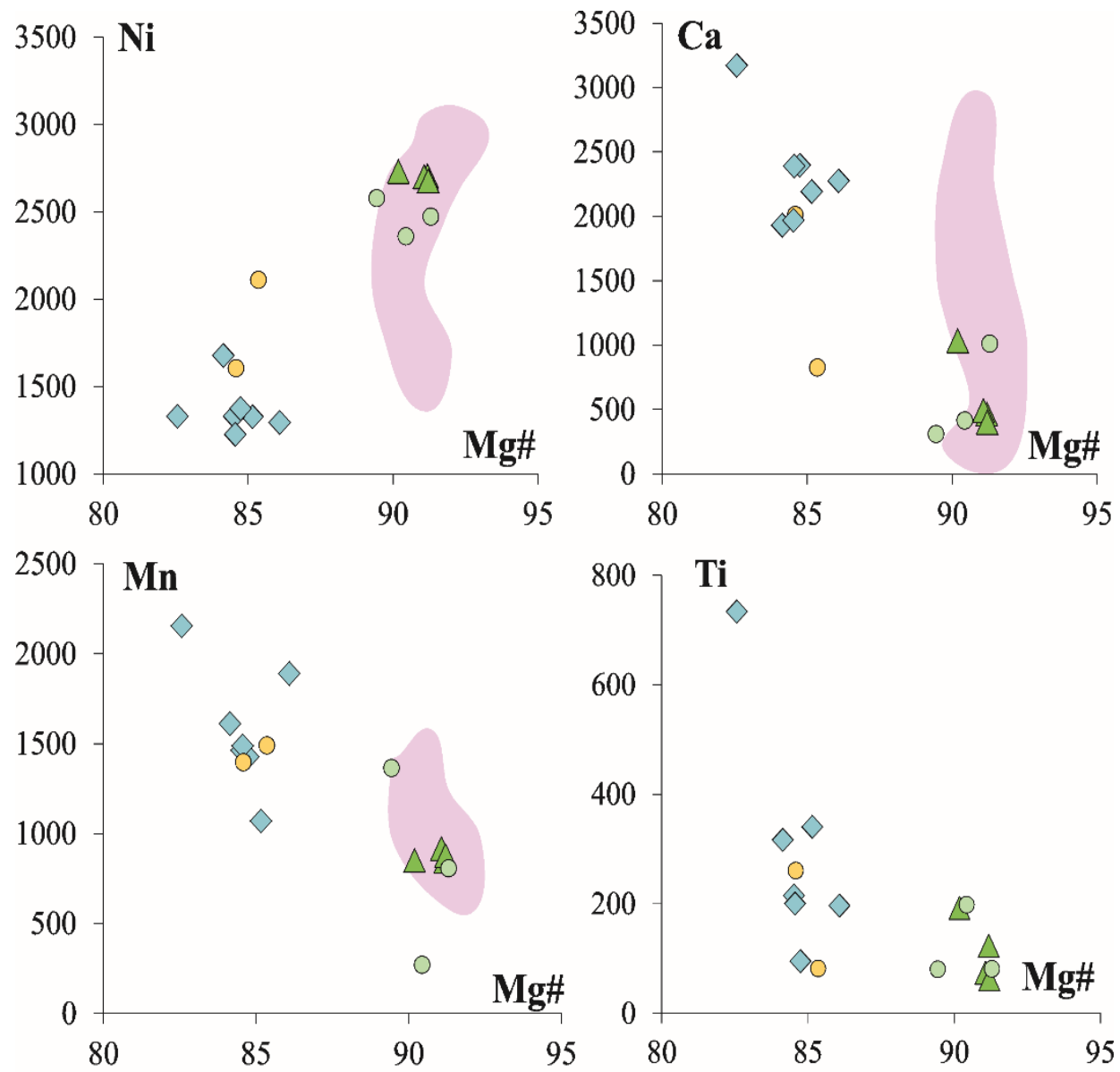

Ol-Ph: $\circ$ Core

○ Rim

$\diamond$ Olivine of groundmass 95

Fig. 5.Variational diagrams Mg\# vs microelements in olivine from picrobasalt. The composition field of olivine of dunite and harzburgite xenoliths in alkaline basalt from Lanzarote is plotted (Neumann et al, 1995).

The temperature of crystallization of clinopyroxene obtained using a geothermometer[24] varies in the range of $1100-1180^{\circ} \mathrm{C}$. established that the equilibrium temperature of mineral paragenesis in xenoliths of harzburgite composition varies from 1170 to $870{ }^{\circ} \mathrm{C}$. The higher temperature of the initial melt compared to mantle rocks trapped during its ascentcould could leadto melting and disintegration of the mantle xenoliths. (Aparicio et al. 2006) found in their work that the initial melt could have a basanite composition and temperature $\sim 1200^{\circ} \mathrm{C}$, at which the calcium-siliceous and siliceous sedimentary rocks trapped at a depth of 4-5 km acquired tholeiitic structure. Thus, the calculated temperature is in good agreement with the data of previous researchers.

\section{Conclusion}

Based on the study of picrobasaltic lavas on Lanzarote and the peridotite xenoliths contained in them it was found that (1) the rocks studied belong to the third phase of the eruption (1731 - 1732); their geochemical composition supplements the existing data on the 
geochemistry of rocks of this phase; (2) olivine phenocrysts are xenocrysts and conventionally originated from the disintegration of mantle xenoliths formed in the hightemperature initial melt (more than $1100^{\circ} \mathrm{C}$ ); (3) the initial melt could have a basaltic or basanitic composition.

\section{References}

1. Gavrilenko, M., Herzberg, C., Vidito, C., Carr, M., Tenner, T., Ozerov, A. A Calciumin-Olivine Geohygrometer and its Application to Subduction Zone Magmatism. Journal of Petrology57, 1811-1832 (2016).

2. Carracedo, J.C. \& Troll, V. The Geology of the Canary Islands. 1st Edition. Amsterdam: Elsevier (2016).

3. Contrucci, I., Klingelhoefer, F., Perrot, J., Bartolomé, R., Gutscher, M.-A., Sahabi, M., Malod, J., Rehault, J.-P. The crustal structure of the NW Moroccan continental margin from wide-angle and reflection seismic data. Geophys. J. Int.159, 117-128 (2004).

4. Anguita, F. \&Hernán, F. The Canary Islands origin: a unifying model. J. Volcanol. Geotherm. Res. 103, 1-26 (2000).

5. Gurenko, A.A., Hoernle, K.A., Hauff, F., Schmincke, H.-U., Han, D., Miura, Y.N., Kaneoka, I. Major, trace element and $\mathrm{Nd}-\mathrm{Sr}-\mathrm{Pb}-\mathrm{O}-\mathrm{He}-\mathrm{Ar}$ isotope signatures of shield stage lavas from the central and western Canary Islands: insights into the mantle and crustal processes. Chem. Geol.233, 75-112 (2006).

6. Longpré, M.A., Chadwick, J.P., Wijbrans, J., Iping, R. Age of the El Golfo debris avalanche, El Hierro (Canary Islands): new constraints from laser and furnace 40Ar/39Ar dating. J. Volcanol. Geotherm. Res. 203, 76-80 (2011).

7. Pedrazzi, D., Martí, J. \& Geyer, A. Stratigraphy, sedimentology and eruptive mechanisms in the tuff cone of El Golfo (Lanzarote, Canary Islands). Bull Volcanol. 75, 740 (2013).

8. Fullea, J., Camacho, A. G., Negredo, A. M. Fernández, J. The Canary Islands hot spot: new insights from 3D coupled geophysical-petrological modeling of the lithosphere and uppermost mantle. Earth Planetary Science Letters409, 71-88 (2015).

9. Gómez-Ulla, A., Sigmarsson, O., Gudfinnsson, G. Trace element systematics of olivine from historical eruptions of Lanzarote, Canary Islands: Constraints on mantle source and melting mode. Chemical Geology449, 99-111 (2016).

10. Aparicio, A., Bustillo, M. A., Garcia, R. \&Araña, V. Metasedimentary xenoliths in the lavas of the Timanfaya eruption (1730 - 1736, Lanzarote, Canary Islands): metamorphism and contamination processes. Geol. Mag.143 (2), 181-193 (2006).

11. Banda, E., Dañobeitia, J. J., Suriñach, E. \&Ansorge, J. Features of a crustal structure under the Canary Islands. Earth Planet. Sci. Lett.55, 11-24 (1981).

12. Carracedo, J.C., Badiola, E., Soler, V. Aspectosvolcanológicos y estructurales. Evoluciónpetrológica e implicaciones en riesgovolcánico de la erupción de 1730 en Lanzarote. Islas Canarias. EstudiosGeologicos 46, 25-55 (1990).

13. Carracedo, J.C., Badiola, E., Soler, V. The 1730-1736 eruption of Lanzarote. Canary Islands: a long, high-magnitude basaltic fissure eruption. J. Volcanol. Geotherm.53, 239-250 (1992).

14. De Hoog, J.C.M., Gall, L., Cornell, D.H. Trace-element geochemistry of mantle olivine and application to mantle petrogenesis and geothermobarometry. Chem Geol.270, 196-215 (2010). 
15. Deegan, F.M., Troll, V.R., Barker, A.K., Harris, C., Chadwick, J.P., Carracedo, J.C., Delcamp, A. Crustal versus source processes recorded in dykes from the Northeast volcanic rift zone of Tenerife, Canary Islands. Chemical Geology.334, 324-344 (2012).

16. Foley, S.F., Prelevic, D., Rehfeldt, T., Jacob, D.E. Minor and trace elements in olivines as probes into early igneous and mantle melting processes. Earth Planet SciLett.363, 181-191 (2013).

17. Geldmacher, J., Hoernle, K., van den Bogaard, P., Duggen, S., Werner, R. New 40Ar/39Ar age and geochemical data from seamounts in the Canary and Madeira volcanic province: support for the mantle plume hypothesis. Earth Planet. Sci. Lett. 237, 85-101 (2005).

18. Larrea, P., França, Z., Lago, M., Widom, E., Galé, C., Ubide, T. Magmatic processes and the role of antecrysts in the genesis of Corvo Island (Azores archipelago, Portugal). Journal of Petrology.54, 769-793 (2013).

19. Lundstrom, C.C., Hoernle, K., Gill, J. U-series disequilibria in volcanic rocks from the Canary Islands: plume versus lithospheric melting. Geochim. Cosmochim.Acta67, 4153-4177 (2003).

20. Machin, A.H \&Torrado, P. F. The island and its territory: vulcanism in Lanzarote. A field trip guide. Sixth International Conference on Geomorphology: geomorphology in regions of environmental contrasts. Zaragoza, 7-11 September 2005. 1-39 (2005).

21. Neumann, E. R., Sørensen, V., Simonsen, S.L., Johnsen, K. Gabbroic xenoliths from La Palma, Tenerife, and Lanzarote, Canary Islands: evidence for reactions between Canary Islands melts and old oceanic crust. J VolcanolGeotherm. 103, 313-342 (2000).

22. Neumann, E. R., Wulff-Pedersen, E., Johnsen, K., Andersen, T., Krogh, E. Petrogenesis of spinel harzburgite and dunite suite xenoliths from Lanzarote, eastern Canary Islands: Implications for the upper mantle. Lithos.35(1-2), 83-107 (1995).

23. Okina, O. I., Lyapunov, S. M., Dubensky, A. S. et al. Ensuring the reliability of the results of trace element analysis of rocks by inductively coupled plasma mass spectrometry (ICP-MS). Bull. MOIP. Geological Department92, 93-100 (2017).

24. Putirka, K. Thermometers and Barometers for Volcanic Systems. Reviews in Mineralogy \& Geochemistry.69, 61-120 (2008).

25. Roeder, P.E. \&Emslie, R.F. Olivine-liquid equilibrium. Contrib. Mineral. Petrol.29, 275-289 (1970).

26. Søager, N., Portnyagin, M., Hoernle, K. et al. Olivine major and trace element compositions in Southern Payenia basalts, Argentina: evidence for pyroxeniteperidotite melt mixing in a back-arc setting. J. Petrol.56, 1495-1518 (2015).

27. Sobolev A.V., Hofmann, A.W., Sobolev, S.V., Nikogosian, I.K. An olivine-free mantle source of Hawaiian shield basalts. Nature. 434, 590-597 (2005).

28. Sobolev, A.V., Hofmann, A.W., Kuzmin, D.V. et al. The amount of recycled crust in sources of mantle-derived melts. Science. 316 (5823), 412-417 (2007).

29. Sun, S.-s. \& McDonough, W. F. Chemical and isotopic systematics of oceanic basalts: implications for mantle composition and processes. Geological Society, London, Special Publications42, 313-345 (1989).

30. Widom, E., Hoernle, K.A., Shirey, S.B., Schmincke, H.-U. Os isotope systematics in the Canary Islands and Madeira: lithospheric contamination and mantle plume signatures. J. Petrol.40, 297-314 (1999). 